\title{
Ultra-wide field imaging of retinopathy of prematurity (ROP) using Optomap-200TX
}

\author{
Sofia Theodoropoulou, ${ }^{1}$ Sean Ainsworth, ${ }^{2}$ Andrew Blaikie ${ }^{1}$
}

${ }^{1}$ Department of Ophthalmology, Victoria Hospital, Kirkcaldy, UK ${ }^{2}$ Department of Neonatal Unit, Victoria Hospital, Kirkcaldy, UK

\section{Correspondence to} Dr Andrew Blaikie andrew.blaikie@nhs.net
To cite: Theodoropoulou $S$, Ainsworth S, Blaikie A. BMJ Case Rep Published online: [please include Day Month Year] doi:10.1136/bcr-2013200734

\section{DESCRIPTION}

A 25 weeks gestation $(870 \mathrm{~g})$ baby developed 'threshold' retinopathy of prematurity (ROP) at 37 weeks corrected gestational age (CGA) requiring treatment to prevent blindness. Severe bronchopulmonary dysplasia meant she was unfit for general anaesthesia necessary for a conventional destructive laser treatment (the current standard of care). Intravitreal antivascular endothelial growth factor drugs (VEGF) ${ }^{1}{ }^{2}$ are emerging as effective treatment for proliferative retinopathies in adults and aggressive ROP in neonates. Our patient received single 'off-label' ranibizumab injection to each eye under topical anaesthesia.

We monitored subsequent progress of retinal vascularisation by conventional binocular indirect ophthalmoscopy and non-contact scanning laser fundus imaging (Optomap Panoramic 200 camera). This has become widely available ( $>2500$ systems installed worldwide) largely in adult private practice eye-care settings. ${ }^{3}$ Optomap uses scanning lasers to create ultra-wide field retinal

A

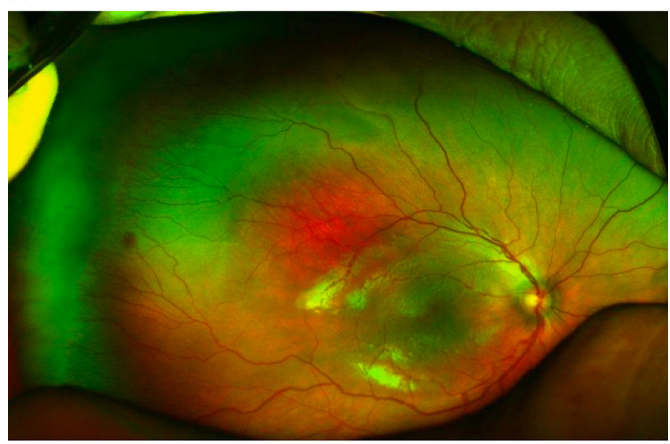

B

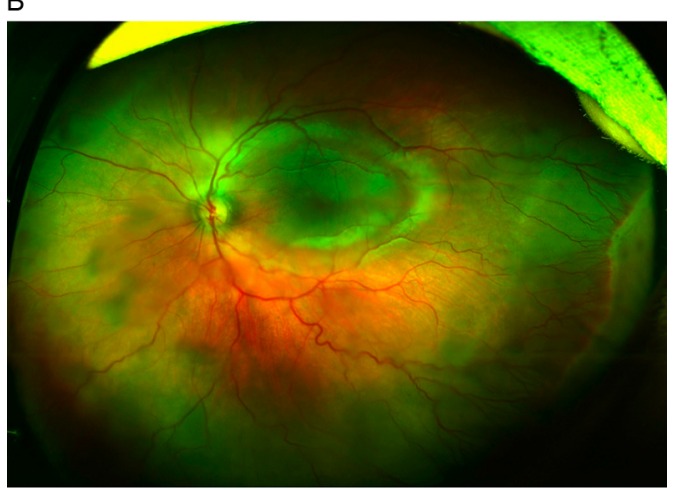

Figure 1 ( $A$ and $B$ ) Wide field fundal images of the right and left eyes respectively 20 weeks after treatment with ranibizumab. images as far as the ora serrata (essential for ROP screening) without ocular contact. ${ }^{3}$ The retina progressively vascularised without developing further 'threshold' ROP. Our images (57 weeks CGA and 20 weeks after treatment) show mild ROP in both eyes (figures 1 and 2). Figure $1 \mathrm{~A}$ demonstrates stage 1 zone III ROP. Figure $1 \mathrm{~B}$ shows predominantly stage 2 zone III ROP. More peripherally there is a zone of pale avascular retina awaiting vascularisation. Figure $2 \mathrm{~A}$ and $2 \mathrm{~B}$ show a subtle demarcation line (arrows) where the leading edge of retinal vascularisation had been at the time treatment. The area between this line and the current edge of vascularisation represents 'gained' functional retina by not performing destructive laser treatment.

This technique offers clear high-resolution noncontact imaging of the far peripheral retina without the need for anaesthesia, speculum, indenter or contact RetCam imaging. In this baby the anti-VEGF therapy has successfully treated the ROP.

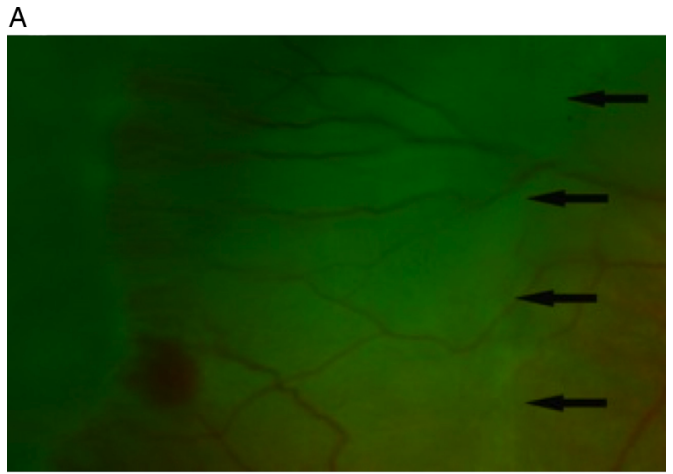

B

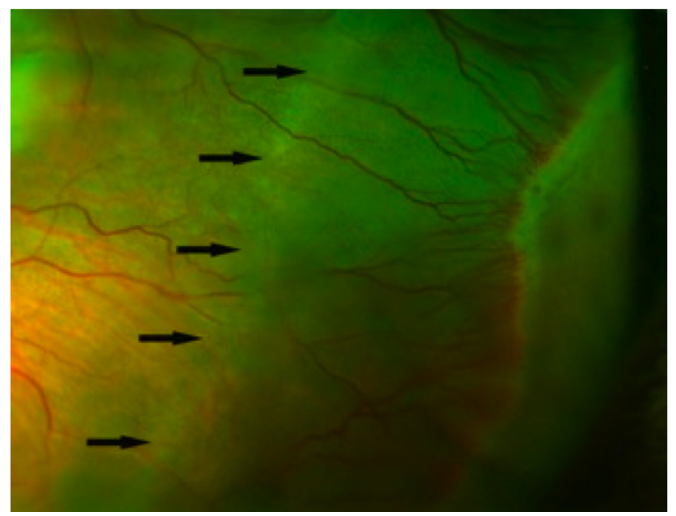

Figure 2 ( $A$ and $B$ ) High magnification images of the temporal peripheral retina of the right and left eyes, respectively. 


\section{Learning points}

- Our fundus imaging with the Optos Optomap panoramic 200TX allowed a reliable examination of the posterior pole covering approximately $180-200^{\circ}$.

- Our images show how vasculogenesis progresses in the retina of a baby with retinopathy of prematurity treated with anti-VEGF therapy (ranibizumab).

- The ultra-wide field 200TX SLO may offer ultra-wide field images of sufficient quality for retinopathy of prematurity screening, without the routine use of anaesthesia, a speculum, indenter or contact RetCam imaging.

Contributors All authors have made an individual contribution to the writing of this article. $A B$ was involved in the conception and design. ST, $S A$ and $A B$ were involved in acquisition of data or analysis and interpretation of data. ST and $A B$ were responsible for drafting the article. $S A$ and $A B$ were involved in revising it critically for important intellectual content. $A B$ was responsible for the final approval of the version to be published.

Competing interests None.

Patient consent Obtained.

Provenance and peer review Not commissioned; externally peer reviewed.

\section{REFERENCES}

1 Mintz-Hittner HA, Best LM. Antivascular endothelial growth factor for retinopathy of prematurity. Curr Opin Pediatr 2009;21:182-7.

2 Castellanos MA, Schwartz S, García-Aguirre G, et al. Short-term outcome after intravitreal ranibizumab injections for the treatment of retinopathy of prematurity. $\mathrm{Br} J$ Ophthalmol 2013;97:816-19.

3 Neubauer AS, Kernt M, Haritoglou C, et al. Nonmydriatic screening for diabetic retinopathy by ultra-wide field scanning laser ophthalmoscopy (Optomap). Graefes Arch Clin Exp Ophthalmol 2008;246:229-35.

Copyright 2013 BMJ Publishing Group. All rights reserved. For permission to reuse any of this content visit http://group.bmj.com/group/rights-licensing/permissions.

BMJ Case Report Fellows may re-use this article for personal use and teaching without any further permission.

Become a Fellow of BMJ Case Reports today and you can:

- Submit as many cases as you like

- Enjoy fast sympathetic peer review and rapid publication of accepted articles

- Access all the published articles

- Re-use any of the published material for personal use and teaching without further permission

For information on Institutional Fellowships contact consortiasales@bmjgroup.com

Visit casereports.bmj.com for more articles like this and to become a Fellow 